\title{
New Object and New Place Reactions of Rattus meltada
}

\author{
Girish CHOPRA \& M. L. SOOD
}

\begin{abstract}
Chopra G. \& Sood M. L., 1983: New object and new place reactions of Rattus meltada. Acta theriol., 29, 33: 403-412 [With 2 Tables \& 7 Figs.]. The behaviour of the soft-furred field rat, Rattus meltada (Gray), was studied in an artificial environment, a "plus" maze. The maze consisted of a central nest box and four arms. Food and water were placed in different arms. A detailed analysis of habituation to the artificial environment, and of reactions towards novelty was made. The rats usually avoided new objects placed in a familiar place but showed little hesitation to explore a previously inaccessible area. The rats generally stopped avoiding strange objects placed near food within 2 to $\delta$ day 3 even when an alternative source of food was available elsewhere.

[Department of Zoo ogy, Punjab Agricultural University, Ludha:a141004, India]
\end{abstract}

\section{INTRODUCTION}

New-object and new-place reactions of various rodent species vary considerably both intraspecifically and interspecifically. Barnett (1958) illustrated a range of new-object reactions among a group of wild Rattus norvegicus.

Common brown rats, $R$. norvegicus often display new-object reaction in a familiar place (Chitty \& Shorten, 1946; Shorten, 1954). Unlike brown rats, laboratory white strains quickly approach and investigate unfamiliar objects (Barnett, 1958; Berlyne, 1960). Watson (1954) demonstrated: a difference in the neophobic behaviour of black rat, Rattus rattus and brown rat, $R$. norvegicus. His black rats often entered bait containers, whereas, avoidance was shown by $R$. norvegicus. Drummond (1960), on the other hand, reported partial avoidance of fresh patches of poisonous dust by $R$. rattus.

Unlike new objects, new areas are quickly explored by both wild and laboratory rats (Greaves \& Rowe, 1969; Ewer, 1971; Barnett, 1975). Cowan and Barnett (1975) obserwed that commensal $R$. rattus quickly approach and investigate previously unexposed areas but avoid strange objects placed in the familiar area. Wild $R$. rattus, however, do not avoid strange objects if they are present when the rats are first introduced, but such objects do evoke avoidance if introduced after rats have adapted to their environment (Cowan, 1976). 
The present experiments were conducted on Rattus meltada (Gray) with an aim to study their behaviour towards novelty.

\section{MATERIALS AND METHODS}

Soft-furred field rats, $R$. meltada were brought from sugarcane fields to the laboratory and thereafter caged independently. Twelve adult rats $(6$ males and 6 females) were utilized in three experiments conducted in a "plus" maze. Six rats (3 males and 3 females) utilized in the experiment 1, were reutilized in experiment 2. The other six rats were utilized in experiment 3. The "plus" maze (Fig. 1) consisted of a central nest box $(21 \times 21 \times 16.5 \mathrm{~cm})$ and four arms radiating from it, each having the dimensions $21 \times 15 \times 15 \mathrm{~cm}$. The arms were covered from the top with glass but the nest box had an opaque lid. The nest box also had a thin layer of sawdust.

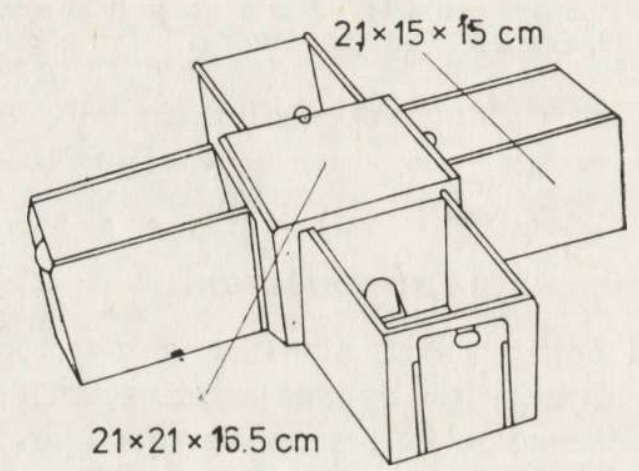

Fig. 1. The "plus" maze.

As the unfamiliar objects were plastic cylinders weighing about $10 \mathrm{~g}$, these provided no physical barrier and could be easily moved by the rats from an arm to the nest box.

Experiment 1. In experiment 1, to study the new-object reaction, each rat was kept in the maze for 8 days; arm A contained food, arm B water, arm C was left empty and arm D contained rubber cork. Rats were weighed to the nearest $1.0 \mathrm{~g}$ at the beginning and end of the experiment. The consumption of food and water was recorded to the nearest $0.1 \mathrm{~g}$ and $0.5 \mathrm{ml}$ respectively. Food and water were replenished daily. The numbers of visits and the time spent in each arm were recorded daily between 20.30 and $23.00 \mathrm{hrs}$ under dim red light. On the 5th day, two cylinders weighing about $10 \mathrm{~g}$ were placed in arm A, midway between the nest and the food basket, and were left in the arm for the remainder of the experiment.

Experiment 2. The new-object reaction was also studied by providing the rats millet grains (Pennisetum typhoidium) at two feeding points. The initial habituation to the maze environment by the rats (experiment 1 ) was used as the basis against which to measure the response to a change at one feeding point. Each rat spent 12 days in the maze. Arms A and C contained food, arm B water and arm D was left empty. Daily observations of the visits in the arms, time 
spent there and the consumption of food and water were recorded as before. After readings had been taken on day 6, two cylinders weighing about $10 \mathrm{~g}$ were placed in the food arm A, midway between the food basket and the opening of the nest box. Thereafter, daily readings were taken as before and, at the same time, the cylinders were returned to their original positions unless they had been carried into the nest box. The rats were weighed before and after their stayl in the maze.

Experiment 3. To study the new place reaction, another 6 rats (three males and three females) were observed in the "plus" maze. Arm A contained food, arm B water, arm C was left empty and access to arm D was blocked for the first four days. Daily observations of the visits to each arm, time spent there and the consumptions of food and water were recorded as before. After readings had been taken on day 4 , arm $\mathrm{D}$ which had been blocked, was opened.

\section{RESULTS}

Experiment 1

The presence of unfamiliar objects in a familiar place that is, near the feeding point, had a marked effect on behaviour of the metads.
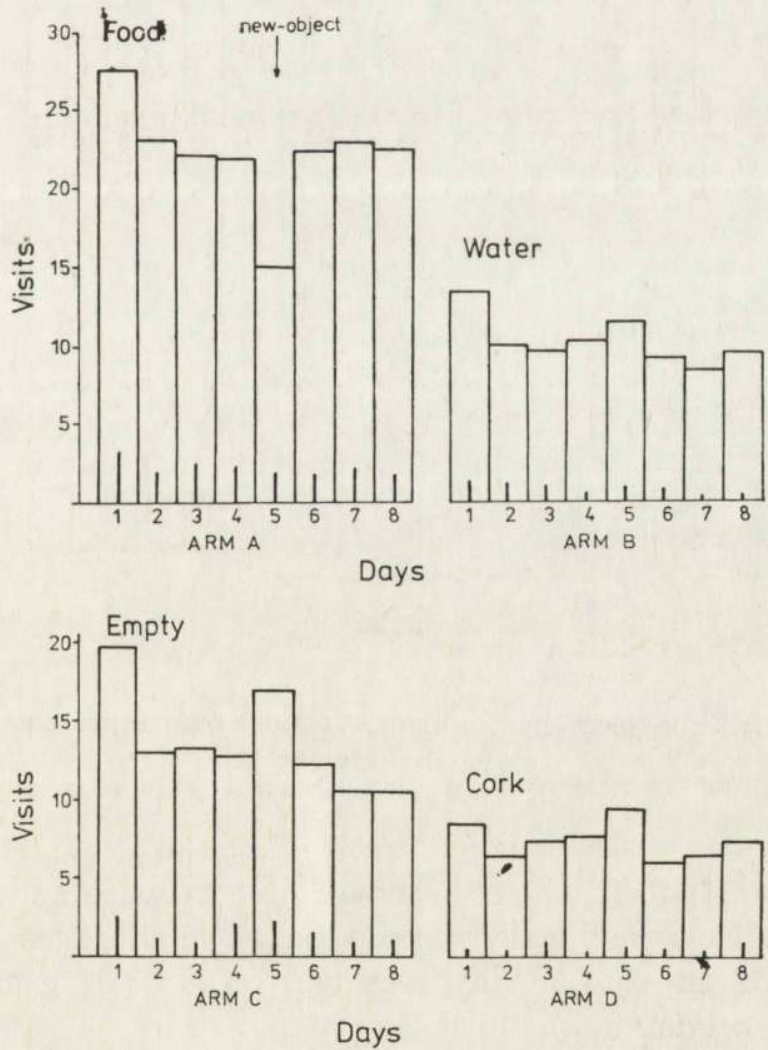

Fig. 2. Mean daily visits to the arms. Vertical bars represent standard errors. $\mathrm{n}=6$ (Experiment 1$)$. 
The rats displayed a typical new object reaction (neophobia) lasting for one day. The number of visits to arm A and the time spent there imarkedly declined $(P<0.01$ for both visit and duration, paired comparisons t-test) on day 5 as compared to those on day 4 (Figs. 2,3). The behaviour of the rats in arm B (containing water) was not affected; but the number of visits in arm D (containing cork) and the time spent there increased after the change was introduced. The rats consumed less $(P<0.01$, paired
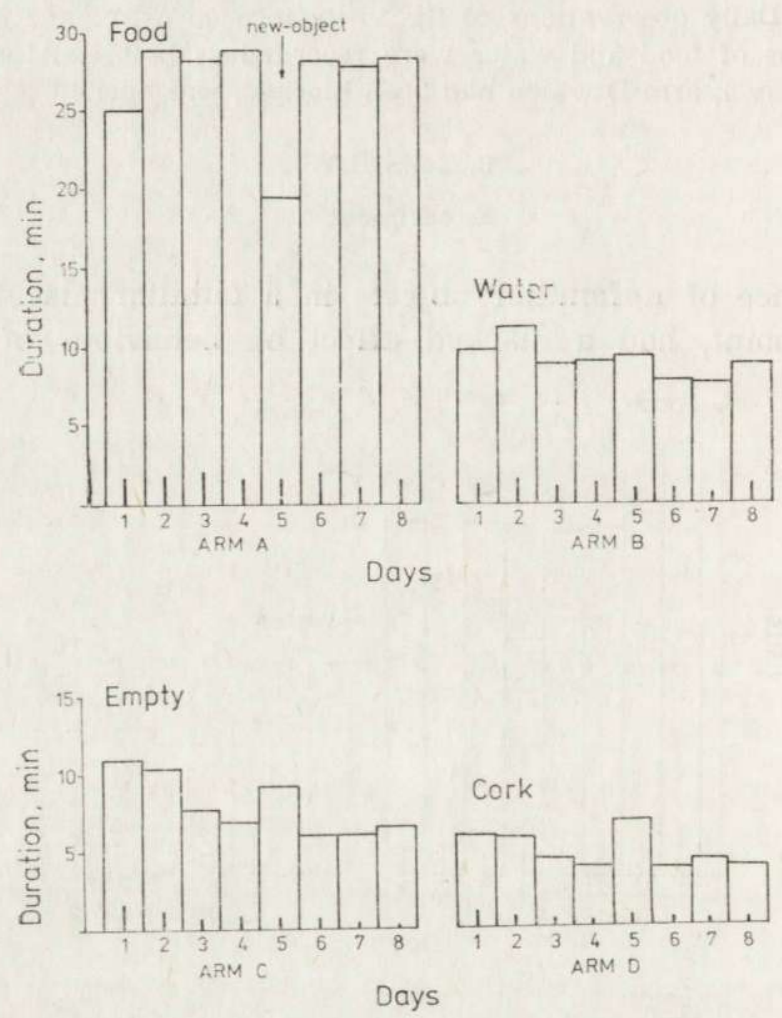

Fig. 3. Mean daily time spent in the arms. Vertical bars represent standard errors. $\mathrm{n}=6$. (Experiment 1).

comparisons $t$-test) food when the novel objects were added to the food arm (Table 1). However, no change in body weights was observed. The mean weight of the rats on day zero was $58.08+3.04 \mathrm{~g}$ and it lessened to $57.92 \pm 3.0 \mathrm{~g}$ on day 8 .

There were more visits to the arms on day 1 than on subsequent .days. The rate of visits stabilized thereafter. 
Table 1

Mean number of visits, time spent and food consumption in experiment 1 (Arm A) before and after the introduction of unfamiliar objects $(n=6)$.

\begin{tabular}{lccc}
\hline Day & $\begin{array}{c}\text { Mean No. of } \\
\text { visits } \pm \text { S.E. }\end{array}$ & $\begin{array}{c}\text { Mean time } \\
\text { spent } \pm \text { S.E. }\end{array}$ & $\begin{array}{c}\text { Mean consumption } \\
\pm \text { S.E. }\end{array}$ \\
\hline 4 & $22.2 \pm 2.3$ & $29.0 \pm 1.7$ & $4.1 \pm 0.3$ \\
5 & $15.2 \pm 1.8^{1}$ & $19.6 \pm 1.6^{1}$ & $3.3 \pm 0.3^{1}$ \\
\hline 1 Significant difference from & 4 th & day reading & (Paired comparison \\
$t$-test, $P<0.01$ ).
\end{tabular}

Experiment 2

To avoid the effect of hunger, two feeding points were made available to the rats in the "plus" maze. As the same six rats used in experiment 1 were reutilized in experiment 2 , their initial habituation to the maze environment was used as the basis against which the response to a change at one feeding place was measured. All the rats increased in weight during the experiment. Mean weight on day zero was $56.83+3.70 \mathrm{~g}$ and on day $12,63.5+5.57 \mathrm{~g}(P<0.01$, paired comparisons $t$-test). Much of the daily activity was recorded in the food arms. Most rats gnawed much more food than they ate. No rat hoarded the excess food in the nest box; they left the spilled food on the floor of the arms. There was no relationship between the food wastage and the response to the novel objects.

The number of visits to arm $\mathrm{A}$ as well as the time spent there declined $(P<0.01$, paired comparisons $t$-test) when unfamiliar objects were introduced in the arm (Figs. 4 and 5). On the other hand, the

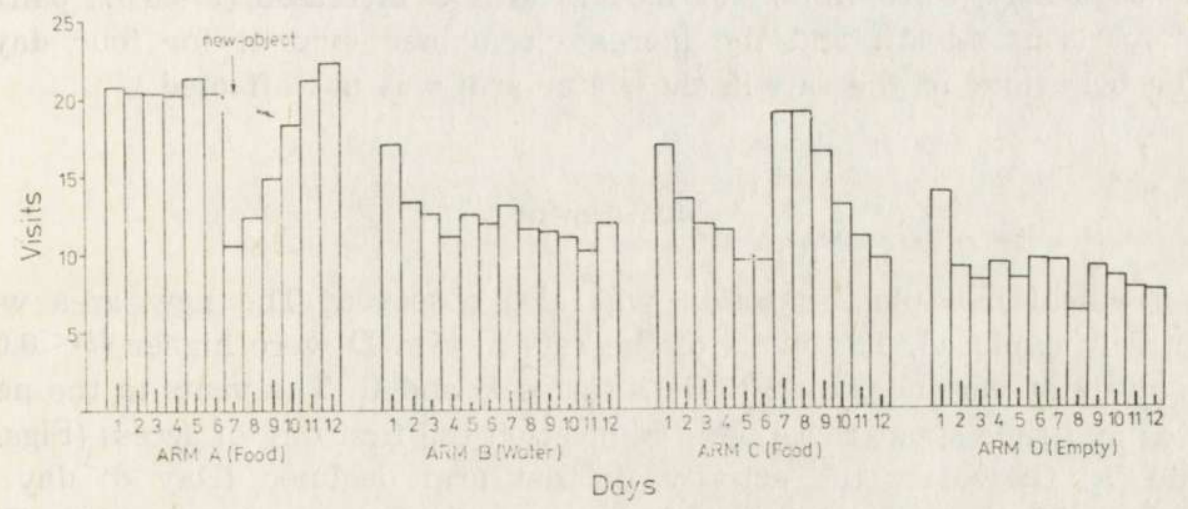

Fig. 4. Mean daily visits to the arms. Vertical bars represent standard errors. $\mathrm{n}=6$. (Experiment 2). 


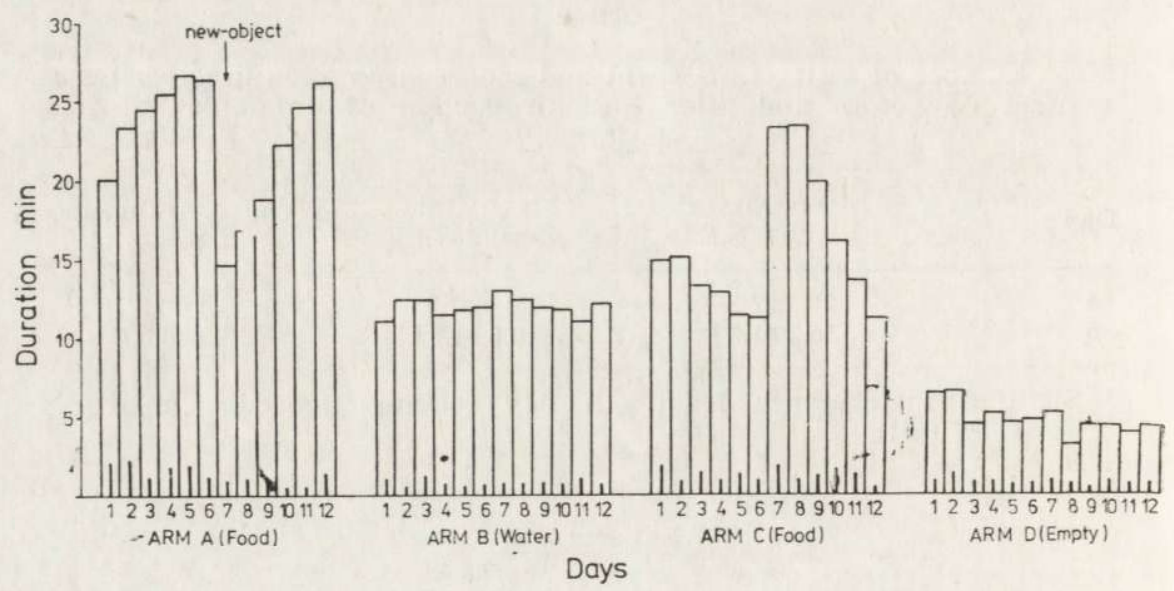

Fig. 5. Mrean daily time spent in the arms. Vertical bars represent standard error. $\mathrm{n}=6$. (Experiment 2).

number of vists to the arm $\mathrm{C}$ and the time spent there increased markedly $(P<0.01$, both for visits and duration) (Table 2). Avoidance lasted for 2 to 3 days. The observations revealed wide variations in behaviour of the rats towards strange objects. One rat avoided the arm for five days, but the other rats showed avoidance for two to three days.

The consumption of food in arm A declined $(P<0.01$, paired comparisons $t$-test) after the changes were introduced in the arm. The decline in food intake lasted for four days. Mean daily intake in arm A was $3.77 \pm 0.23 \mathrm{~g}$ on day 6 , and it declined to $1.28 \pm 0.14 \mathrm{~g}$ on day 7 (Table 2). Consequently, consumption of food in arm $\mathrm{C}$ increased $(P<0.01$, paired comparisons $t$-test); and the increase remained evident for four days. The behaviour of the rats in the water arm was not affected.

\section{Experiment 3}

Typical new-place reaction was also observed. The new area was actively explored. The visits of the rats in arm D were higher $(P<0.05$, analysis of variance) than those in arms B and C. The visits to the new area and time spent there were highest on the first day of access (Figs. 6 and 7); thereafter the activity in that arm declined (Day $8<$ day 5 , $P<0.01$, for both visits and duration; paired comparison $t$-test). The activity in the food and water arms was not affected. 


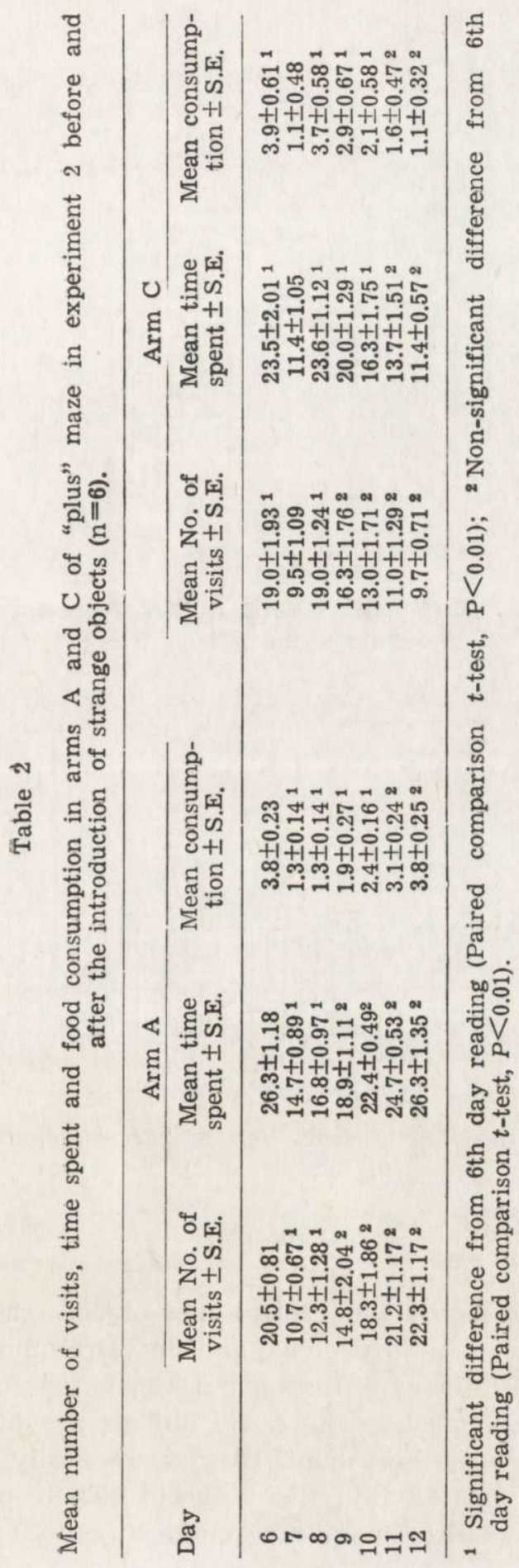




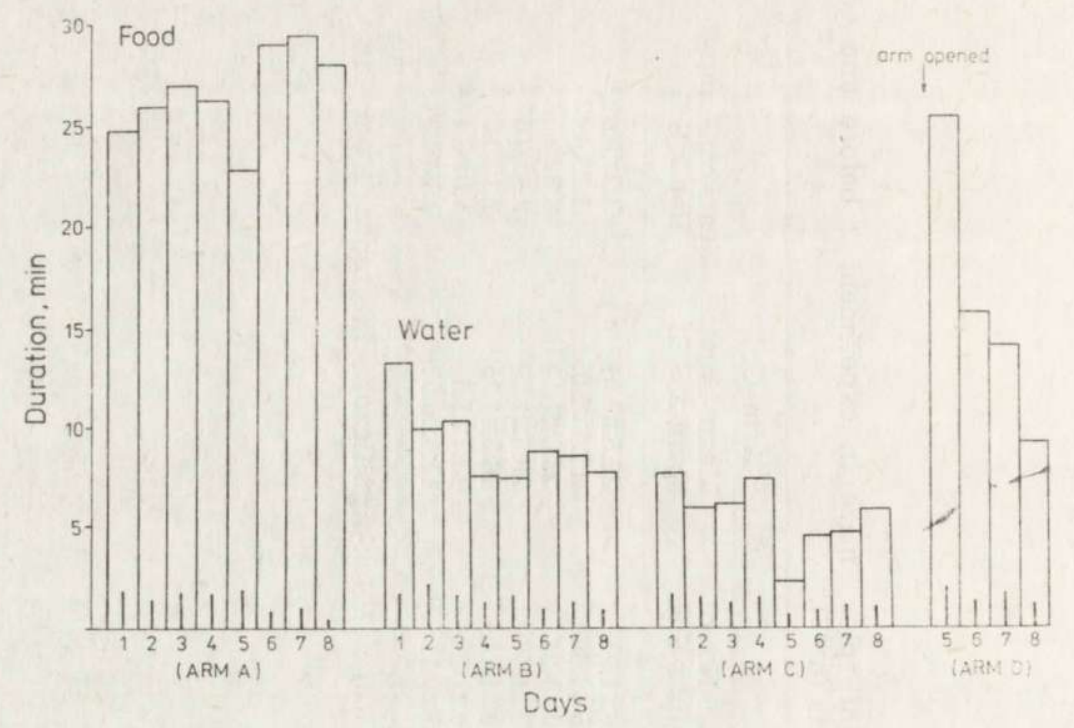

Fig. 6. Mean daily visits to the arms. Vertical bars represent standard errors. $\mathrm{n}=6$. (Experiment 3 ).

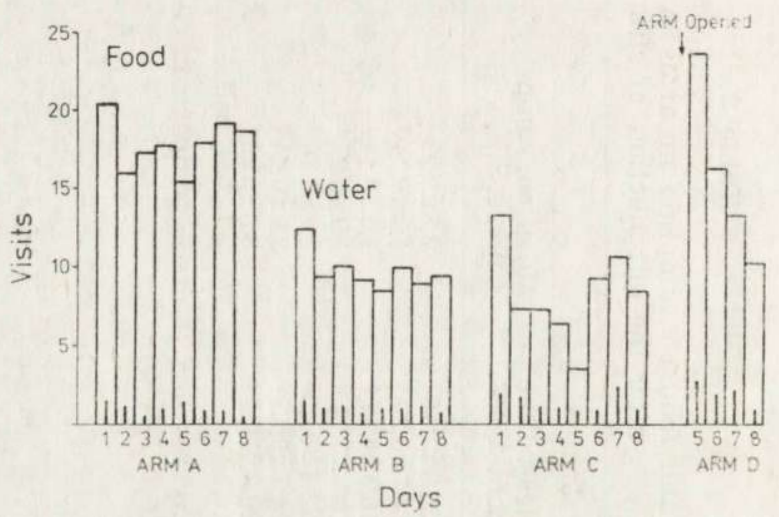

Fig. 7. Mean daily time spent in the arms. Vertical bars represent standard errors. $\mathrm{n}=6$. (Experiment 3 ).

\section{DISCUSSION}

Rattus meltada displayed the typical new-object reaction described by Shorten (1954) for R. norvegicus and by Drummond (1960) and Cowan \& Barnett (1975) for $R$. rattus, but the extent of this reaction varied greatly in these species. The novel objects provided no physical barrier. The objects, weighing about $10 \mathrm{~g}$, were easily moved by the rats and were often carried into the nest box. Their presence in the food arm, however, resulted in a marked decline in rats' activity in 
that arm. Similar observations have also been recorded by Cowan and Barnett (1975) for $R$. rattus. New-object reaction was elicited when the objects unfamiliar in appearance, odour and taste were placed in a throughly familiar area.

Cowan (1976) states that the rats ( $R$. rattus) do not avoid the objects in the "plius" maze if the objects are present when the rats are introduced for the first time. Such objects, however, did evoke new-object reaction if introduced after the rats had adopted to their new environment.

In experiment 1 , in which a single source of food was made available, from which the rats were excluded by neophobia, the decline in avoidance may have been hastened by starvation, as avoidance was prolonged when other food sources were made available. Similarly, in natural conditions, any change in the environment which induces avoidance of a feeding place will usually have little effect on the total food consumption since alternative sources of food are available.

The novel objects were eventually explored by most of the rats even when an alternative source of food was available elsewhere. These observations suggest that the tendency to approach remained at a steady level, while the tendency to withdraw (initially dominant), gradually declined.

The neophobia of Rattus meltada may be the result of selection, in man-made environments, for avoidance of traps and poisoned baits.

New-place reaction was studied by allowing the rats access to an! arm, which had been previously closed. The rats explored the new area mostly on the first day of exposure and the response thereafter declined. Although the new area provided no other incentive than the opportunity to explore, it was regularly visited each day (even when it was already familiar) but little time was spent there. Laboratory mice, pregnant or parturient, behave in the same way (Barnett \& McEwan, 1973).

Acknowledgements: We thank Dr. S. S. Guraya, Professor and Head of the Department of Zoology, for the encouragement and for providing the laboratory facilities and Dr. Ishwar Prakash, Professor of Eminence, CAZRI, Jodhpur, for his valuable suggestions. This research was supported by a grant from the I.C.A.R. scheme. "All India Co-ordinate Research Project on Rodent Control" under the project, entitled, "Behaviour and Ecology of Field Rodents in Punjab".

\section{REFERENCES}

1. Barnett S. A., 1958: Experiments on "neophobia" in wild and laboratory rats. Br. J. Psychol., 49: 195-201.

2. Barnett S. A., 1975: The rat: A study in behaviour. Chicago Univ. Press, Chicago. 
3. Barnett S. A. \& McEwan I., 1973: Movements of virgin, pregnant and lactating mice in a residential maze. Physiol. Behav., 10: 741-746.

4. Berlyne D. E., 1960: Conflict, arousal and curiosity. McGraw Hill Publ., New York (cited in Cowan and Barnett, 1975).

5. Chitty D. \& Shorten M., 1946: Techniques for the study of the norway rat (Rattus norvegicus). J. Mammal., 27: 63-78.

6. Cowan P. E., 1976: The new object reaction of Rattus rattus L.: The relative importance of various areas. Behav. Biol., 16: 31-44.

7. Cowan P. E. \& Barnett S. A., 1975: The new object and new place reactions of Rattus rattus L. Zool. J. Linn. Soc., 56: 219-234.

8. Drummond D. C., 1960: Partial avoidance of a rodenticidal dust by Rattus rattus. Parasitica, 16 1-6.

9. Greaves J. H. \& Rowe F. P., 1969: Responses of confined rodent populations to an ultrasound generator. J. Wildl. Manage., 33: 409-417.

10. Ewer R. F., 1971: The biology and behaviour of a free-living population of black rats (Rattus rattus). Anim. Behav. Monogr., 4 (iii).

11. Shorten M., 1954: The reaction of the brown rat towards changes in its environment. [In: D. Chitty (Ed.), "The control of rats and mice"] Clarendon Press, 2: 307-344. Oxford.

12. Sokolov E. N. 1960: Neuronal models and the orienting reflex. [In: M. A. B. Brazier (Ed.), "The central nervous system and behaviour"]. Josiah Macy Jr. Foundation. New York.

13. Watson J. S., 1954: Control of the ship rat (Rattus rattus) in London. (Cited in Cowan and Barnett, 1975).

Accepted, April 25, 1984.

Girish CHOPRA i M. L. SOOD

REAKCJA RATTUS MELTADA NA NOWE REKWIZYTY I MIEJSCA

\section{Streszczenie}

Do badań nad behawiorem $R$. meltada użyto 12 dorosłych osobników (6 samców i 6 samic), odłowionych na plantacjach trzciny cukrowej. Doświadczenia prowadzono posługując się labiryntem (Ryc. 1), posiadającym w centrum gniazdo o wymiarach $21 \times 21 \times 16,5 \mathrm{~cm}$ i 4 ramiona odchodzące promieniście od niego, przykryte od góry szybką szklaną. W ramionach tych rozmieszczano w różny sposób pokarm i wodę oraz umieszczano w nich później rekwizyty nieznane zwierzętom. Rekwizytami tymi były plastykowe cylindry o wadze ok. $10 \mathrm{~g}$, przez które szczury mogły łatwo przechodzić dostając się do pokarmu lub gniazda. Przeprowadzono analizę zachowania zwierząt, ich przyzwyczajania się do sztucznego środowiska oraz reakcji na nieznane przedmioty. Stwierdzono, że $R$. meltada początkowo rzadziej odwiedza te ramiona labiryntu, w których umieszczano takie rekwizyty, lecz okres ich wahania trwa dość krótko (Tabela 1, 2; Ryc. 2-7). Na ogół po 2 do 3 dniach zwierzęta przestają zwracać na nie uwagę i nie unikają ich nawet wówczas gdy $w$ sąsiednim ramieniu labiryntu jest dostępny pokarm bez dodatkowych utrudnień. 